\title{
CBP as a transcriptional coactivator of $\mathrm{c}-\mathrm{Myb}$
}

\author{
Ping Dai, ${ }^{1}$ Hiroshi Akimaru, ${ }^{1}$ Yasunori Tanaka, ${ }^{1,2}$ De-Xing Hou, ${ }^{1}$ Takashi Yasukawa, ${ }^{1,3}$ \\ Chie Kanei-Ishii, ${ }^{1}$ Tomomi Takahashi, ${ }^{1}$ and Shunsuke Ishii ${ }^{1,4}$ \\ ${ }^{1}$ Laboratory of Molecular Genetics, Tsukuba Life Science Center, The Institute of Physical and Chemical Research (RIKEN), \\ Tsukuba, Ibaraki 305, Japan; ${ }^{2}$ Institute of Biological Sciences and ${ }^{3}$ Institute of Basic Medical Sciences, University of \\ Tsukuba, Tsukuba, Ibaraki 305, Japan
}

CBP (CREB-binding protein) is a transcriptional coactivator of CREB (çAMP response element-binding) protein, which is directly phosphorylated by PKA (CAMP-dependent protein kinase A). CBP interacts with the activated phosphorylated form of CREB but not with the nonphosphorylated form. We report here that CBP is also a coactivator of the c-myb proto-oncogene product (c-Myb), which is a sequence-specific transcriptional activator. CBP directly binds to the region containing the transcriptional activation domain of c-Myb in a phosphorylation-independent manner in vitro. The domain of CBP that touches c-Myb is also required for binding to CREB. A c-Myb/CBP complex in vivo was demonstrated by a yeast two-hybrid assay. CBP stimulates the c-Myb-dependent transcriptional activation. Conversely, the expression of antisense RNA of CBP represses c-Myb-induced transcriptional activation. In addition, adenovirus $E 1 A$, which binds to $C B P$, inhibits c-Myb-induced transcriptional activation. Our data thus identify CBP as a coactivator of c-Myb. These results suggest that CBP functions as a coactivator for more transcriptional activators than were thought previously.

[Key Words: CBP; Myb; coactivator; CREB; adenovirus E1A]

Received August 30, 1995; revised version accepted January 23, 1995.

The c-myb proto-oncogene is the cellular progenitor of the $\mathrm{v}-m y b$ oncogenes carried by the chicken retroviruses AMV and E26, which transform myelomonocytic hematopoietic cells (for review, see Graf 1992). The level of expression of $c-m y b$ is high in immature cells of various hematopoietic lineages and is down-regulated during terminal differentiation (Westin et al. 1982; Gonda and Metcalf 1984; Duprey and Boettiger 1985). Artificial expression of $c-m y b$ blocks the induced differentiation of immature erythroid cells /Clarke et al. 1988; Todokoro et al. 1988), and treatment with an antisense oligonucleotide directed to c-myb blocks the proliferation of precursor cells (Gewirtz and Calabretta 1988). Furthermore, homozygous c-myb mutant mice are severely anemic and die in utero because of defective fetal hematopoiesis (Mücenski et al. 1991). Therefore, c-Myb is important in maintaining the proliferative state of immature hematopoietic cells.

c-Myb is a transcriptional activator that binds to a specific DNA sequence, AACNG (Biedenkapp et al. 1988; Nakagoshi et al. 1990; Tanikawa et al. 1993). Both artificial promoter constructs containing c-Myb-binding sites (Nishina et al. 1989; Weston and Bishop 1989; Nakagoshi et al. 1990) and natural promoters such as the mim-1 and c-myc genes (Ness et al. 1989; Evans et al.

${ }^{4}$ Corresponding author.
1990 are activated by c-Myb. Deletion analyses of c-Myb indicates that it has three functional domains responsible for DNA binding, transcriptional activation, and negative regulation (Sakura et al. 1989). The DNA-binding domain in the amino-terminal region of c-Myb consists of three imperfect tandem repeats of 51-52 amino acids, each containing a helix-turn-helix variation motif (Sakura et al. 1989; Ogata et al. 1992, 1995). The second and third repeats are closely packed in the major groove of the DNA, and the two recognition helices in these repeats bind to the specific base sequence cooperatively (Ogata et al. 1994). The transcriptional activation domain of c-Myb, which is rich in acidic amino acids, is adjacent to the DNA-binding domain. Two c-myb-related genes, A-myb and B-myb, were identified by crosshybridization (Nomura et al. 1988). A-Myb has a very similar structure of functional domains to $\mathrm{c}-\mathrm{Myb}$ and is the strongest transcriptional activator among the three members of the myb gene family (Golay et al. 1994; Trauth et al. 1994; Takahashi et al. 1995). On the other hand, B-Myb is a cell-type-specific transcriptional activator, and the specific cofactor that binds to the carboxyproximal portion appears to be required for transcriptional activation by B-Myb (Tashiro et al. 1995).

The RNA polymerase II transcriptional machinery is composed of the enzyme and a complement of accessory factors (TFIIA, TFIIB, TFIID, TFIIE, TFIIF, and TFIIH) (for 
review, see Buratowski 1994). Among these, only TFIID is a sequence-specific DNA-binding protein composed of the TATA-binding protein (TBP) and multiple TBP-associated factors (TAFs) (Goodrich and Tjian 1994). Several TAFs are essential as coactivators of transcription through their interaction with specific enhancer-binding activators (Tjian and Maniatis 1994). Different transcriptional activators target distinct TAFs in the TFIID complex for their functional activation of transcription. However, there is no information about the coactivator for c-Myb that binds to its acidic activation domain.

CBP (CREB-binding protein) is a transcriptional coactivator of CREB (cAMP response element-binding protein) that binds to the $\overline{\mathrm{A}} \overline{\mathrm{A}} \mathrm{PP}$ response element (CRE), TGACGTCA (Chrivia et al. 1993; Kwok et al. 1994). An increase in intracellular CAMP concentration leads to the activation of the cAMP-dependent protein kinase A (PKA) that directly phosphorylates CREB at Ser-133 (Gonzalez and Montminy 1989). This Ser-133 is in the transcriptional activation domain, and CBP binds to CREB only when Ser-133 is phosphorylated. As CBP interacts with TFIIB, which contacts TBP and also functions in the recruitment to the promoter of RNA polymerase II, CBP mediates CREB-dependent transcriptional activation as a bridge between phosphorylated CREB and the RNA polymerase II complex. Thus, the phosphorylation-dependent binding of CBP to CREB is a critical step for transcriptional activation through the cAMP pathway. Microinjection of anti-CBP antiserum into fibroblasts inhibited transcription from the promoter containing not only CRE but also a TPA response element (TRE) and serum response element (SRE) (Arias et al. 1994). In addition, CBP was suggested to bind to c-Jun phosphorylated by c-Jun amino-terminal kinase [JNK; also known as stress-activated protein kinases (SAPK)|. These facts suggest that CBP functions as a coactivator for certain phosphorylated activators. In mammals, the CBP gene family has two members, CBP and p300 (Arany et al. 1994). p300 was originally identified as a protein that binds to the adenovirus E1A protein (Eckner et al. 1994). Both CBP and p300 are large proteins composed of $\sim 2400$ amino acids and have high homology overall. Recently, CBP was also shown to bind to ElA, and in addition, p300 was found to function as a coactivator of CREB, indicating that the proteins have very similar functions (Arany et al. 1995; Lundblad et al. 1995). The CREB-binding domain is localized in the amino-proximal region of CBP and p300, whereas the ElA-binding domain is in the carboxy-proximal region. Binding of E1A to CBP inhibits CREB-induced transcriptional activation. The recent finding that RubinsteinTaybi syndrome is associated with mutations in CBP indicates the important physiological role of CBP (Petrij et al. 1995).

We report here that CBP binds to the activation domain of c-Myb and functions as a coactivator. Our results indicate that CBP not only interacts with phosphoCREB but also other transcription factors in a phosphorylation-independent manner. Thus, CBP may be a more general coactivator than was thought previously.

\section{Results}

Specific binding of CBP to the nonphosphorylated form of $c-M y b$

Recently we have identified a Drosophila mutant of the CBP gene (dCBP), and found that the tissue and developmental stage specificity of its expression is very similar to that of the Drosophila myb gene $\{\mathrm{H}$. Akimaru and $\mathrm{S}$. Ishii, unpubl.). This allowed us to speculate that CBP may function as a coactivator of $c-M y b$. To test this, we first examined whether CBP interacts directly with c-Myb (Fig. 1). Protein affinity resins, in which the glutathione $S$-transferase (GST) or GST-CBP fusion protein containing the 201-amino-acid region of CBP was used as a ligand, were prepared (Fig. 1A). This 201-amino-acid region of $\mathrm{CBP}$ contains the domain responsible for binding to the phosphorylated CREB (Chrivia et al. 1993). The full-length form of mouse c-Myb was synthesized using an in vitro transcription/translation system and mixed with this affinity resin. Approximately $15 \%$ of input c-Myb bound to the resin containing the GST-CBP fusion protein but not to GST resin at all (Fig. 1B, lanes $1-3 \mid$. We confirmed that the in vitro-translated CREB bound to this GST-CBP resin $(\sim 12 \%$ of input) only when the in vitro-synthesized CREB was treated with the catalytic subunit of PKA (Fig. 1B, lanes 5-8). However, $c-M y b$ bound to the GST-CBP resin without treatment with PKA, and the PKA treatment did not increase the efficiency of binding of $\mathrm{c}-\mathrm{Myb}$ to CBP (Fig. 1B, cf. lanes 3 and 4). To examine the possibility that the in vitro-translated $\mathrm{c}-\mathrm{Myb}$ is already phosphorylated by some kinases and that this is why PKA treatment did not affect the binding to CBP, we treated the in vitro-translated $\mathrm{c}-\mathrm{Myb}$ with potato acid phosphatase and then used it for a binding assay. Previously, we showed that 0.08 unit of phosphatase was sufficient to dephosphorylate the transcription factor HIV-TF1 and decrease its DNAbinding activity (Maekawa et al. 1991b). In this study we used 120-fold more phosphatase (10 units) to treat the in vitro-translated $\mathrm{c}-\mathrm{Myb}$, but the phosphatase treatment did not affect the binding of c-Myb to CBP (Fig. 1C, lanes 1-6). In addition, the full-length form of c-Myb that was produced as a soluble form in Escherichia coli also bound to the GST-CBP resin efficiently $(\sim 10 \%$ of input) (Fig. 1C, lanes 7-9). These results indicate that CBP binds to nonphosphorylated c-Myb.

\section{In vitro binding of $C B P$ to the region containing the activation domain of $c-M y b$}

To examine further whether CBP interacts with the activation domain of $\mathrm{c}-\mathrm{Myb}$, which is rich in acidic amino acids, we used deletion mutants of c-Myb for a binding assay (Fig. 2A,B). We had identified the region between amino acids 238 and 325 as a transcriptional activation domain (Sakura et al. 1989). The $\Delta$ TA mutant lacking this activation domain still partly retained the capacity to bind to CBP. About $12 \%$ of the input wild-type $\mathrm{c}-\mathrm{Myb}$ protein bound to the GST-CBP resin, and $6 \%$ of the input $\triangle \mathrm{TA}$ bound. The weaker binding activity of $\Delta \mathrm{TA}$ was 
A

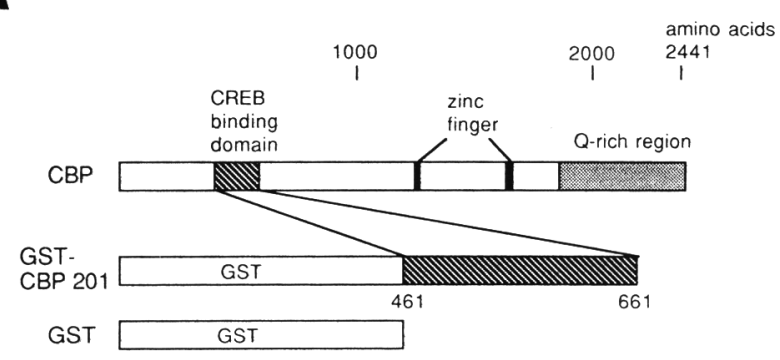

Figure 1. Binding of $\mathrm{c}-\mathrm{Myb}$ to $\mathrm{CBP}$ in vitro. $|A|$ Schematic representation of the GST-CBP fusion protein used as a ligand. |Top) The structure of murine CBP is shown schematically. The structures of GST-CBP fusion protein containing the CREB-binding domain (amino acids 461-661) and GST are indicated below. $(B)$ Direct binding of in vitro-translated $\mathrm{C}-\mathrm{Myb}$ or CREB to the GST-CBP resin. The Sepharose resin containing GST-CBP (lanes $3,4,7,8$ ) or GST (lanes 2,6 ) as a ligand was mixed with in vitro-translated ${ }^{35} \mathrm{~S}$-labeled $\mathrm{c}-\mathrm{Myb}$ (left) or in vitro-translated ${ }^{35} \mathrm{~S}$-labeled CREB (right). In lanes 4 and 8 , in vitro-translated c-Myb and CREB were treated with PKA before mixing with the resin. After washing, the bound proteins were released and analyzed on 10\% SDS-PAGE followed by autoradiography. In lanes 1 and 5, the amount of ${ }^{35} \mathrm{~S}$-labeled c-Myb or $\left[{ }^{35} \mathrm{~S}\right\}$ CREBwas $10 \%$ that used for binding assay. (C) Phosphorylation-independent binding of $\mathrm{c}-\mathrm{Myb}$ to CBP. In lanes $1-6$, the binding of $\mathrm{c}-\mathrm{Myb}$ to CBP was analyzed similarly with $(+)$ or without $(-)$ treatment of in vitro-translated ${ }^{35}$ S-labeled c-Myb by potato acid phosphatase as described in Materials and methods. Bacterially expressed c-Myb was also mixed with the Seph-

B
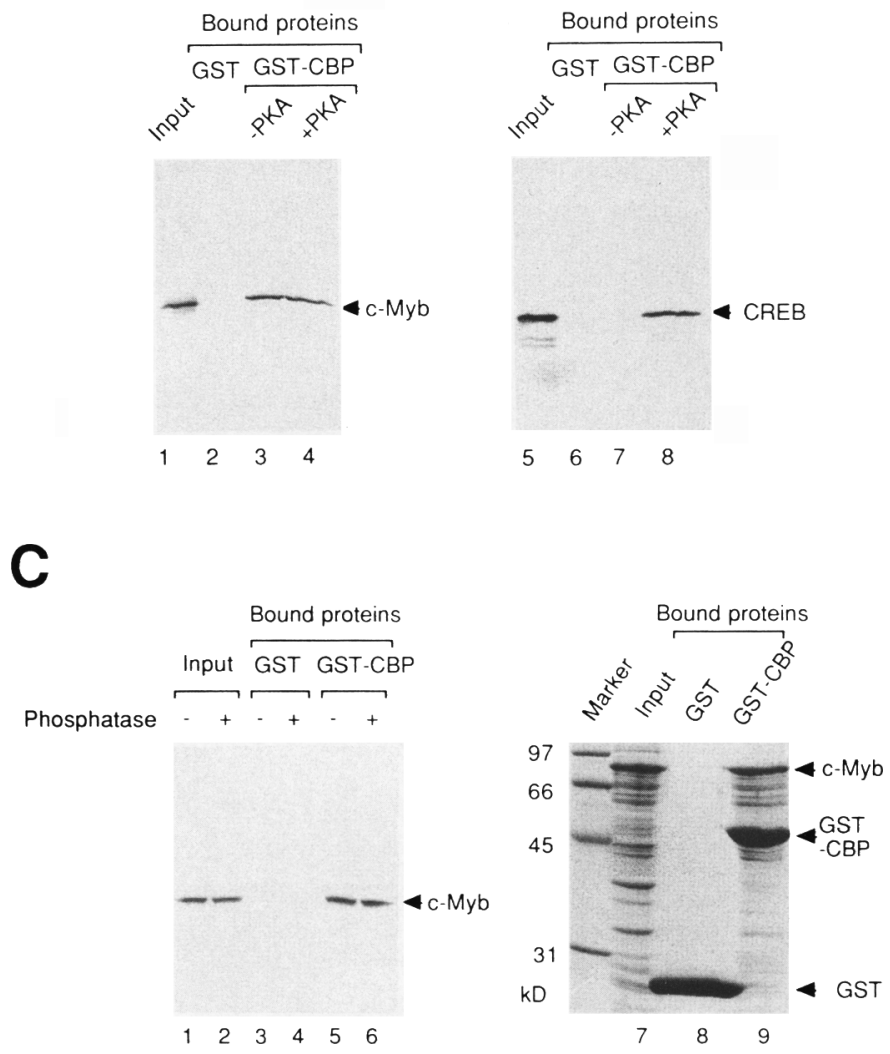
arose resin containing GST (lane 8) or GST-CBP (lane 9), and the bound proteins were analyzed on 10\% SDS-PAGE followed by Coomassie brilliant blue staining. In lanes 1,2 , and 7, 10\% of the protein samples used for binding assays was analyzed.

confirmed by performing the binding assays using increasing amounts of wild-type and $\triangle \mathrm{TA}$ proteins (Fig. 2 C). Consistent with this, the small protein TA, containing only the activation domain, has a CBP-binding activity, but its activity is also lower than that of wild type $(\sim 6 \%$ of the input) (Fig. 2A,B). Again, the weaker binding activity of TA was confirmed by using increasing amounts of TA (Fig. 2C). These results suggest that CBP binds to the region containing the activation domain and its adjacent region. Three carboxy-terminally truncated mutants CT1, CTV, and CT2 bound to CBP as efficiently as wild type $(\sim 10-12 \%$ of the input), but CT5 did not interact with CBP at all. These results indicate that CBP binds to the region between the carboxy-terminal ends of CT5 and CT2 (amino acids 194-401).

\section{Domain of CBP that interacts with $c-M y b$}

We examined whether the domain of $\mathrm{CBP}$ required for interaction with $\mathrm{c}-\mathrm{Myb}$ is the same as the CREB-binding domain. In addition to the GST-fusion protein containing the 201-amino-acid region of CBP (amino acids 461$661)$ that was used in Figure 1, three fusion proteins containing the broader 265-amino-acid region (GSTCBP265), and the amino-terminal 129-amino-acid region
(GST-CBP129) or carboxy-terminal 80-amino-acid region (GST-CBP80) of the original 201 amino acids, were prepared and used for binding assays (Fig. $3 \mathrm{~A}, \mathrm{~B}$ ). In the carboxy-terminal 80-amino-acid region /amino acids $590-669$ of CBP), the amino acid sequence is highly conserved between CBP, p300, and the two putative homologs of Caenorhabditis elegans R1OE11.1 and K03H1.10 (Arany et al. 1994; Lundblad et al. 1995). As expected from this highly conserved sequence, phosphorylated CREB bound to this 80 -amino-acid region $(10 \%$ of input) as efficiently as to the 201- and broader 265 amino-acid regions (11\% of input in both cases) and did not bind to its adjacent 129 -amino-acid region $k 1 \%$ of input) (Fig. 3C). Although 15\% of the input c-Myb bound to the 201 - or 265 -amino-acid regions, only $6 \%$ of input $\mathrm{c}-\mathrm{Myb}$ bound to this 80 -amino-acid region. To confirm these results, binding assays using increasing amounts of c-Myb and CREB were done (Fig. 3D). The binding affinity of c-Myb to GST-CBP80 was significantly lower than that to GST-CBP265, but phosphorylated CREB bound to these two fusion proteins with almost the same affinity. Thus, the 80-amino-acid region of CBP (amino acids $590-669)$ is required for binding with either phosphorylated CREB or c-Myb, and its adjacent region (amino acids 461-589) increases the binding with c-Myb but not with CREB. 

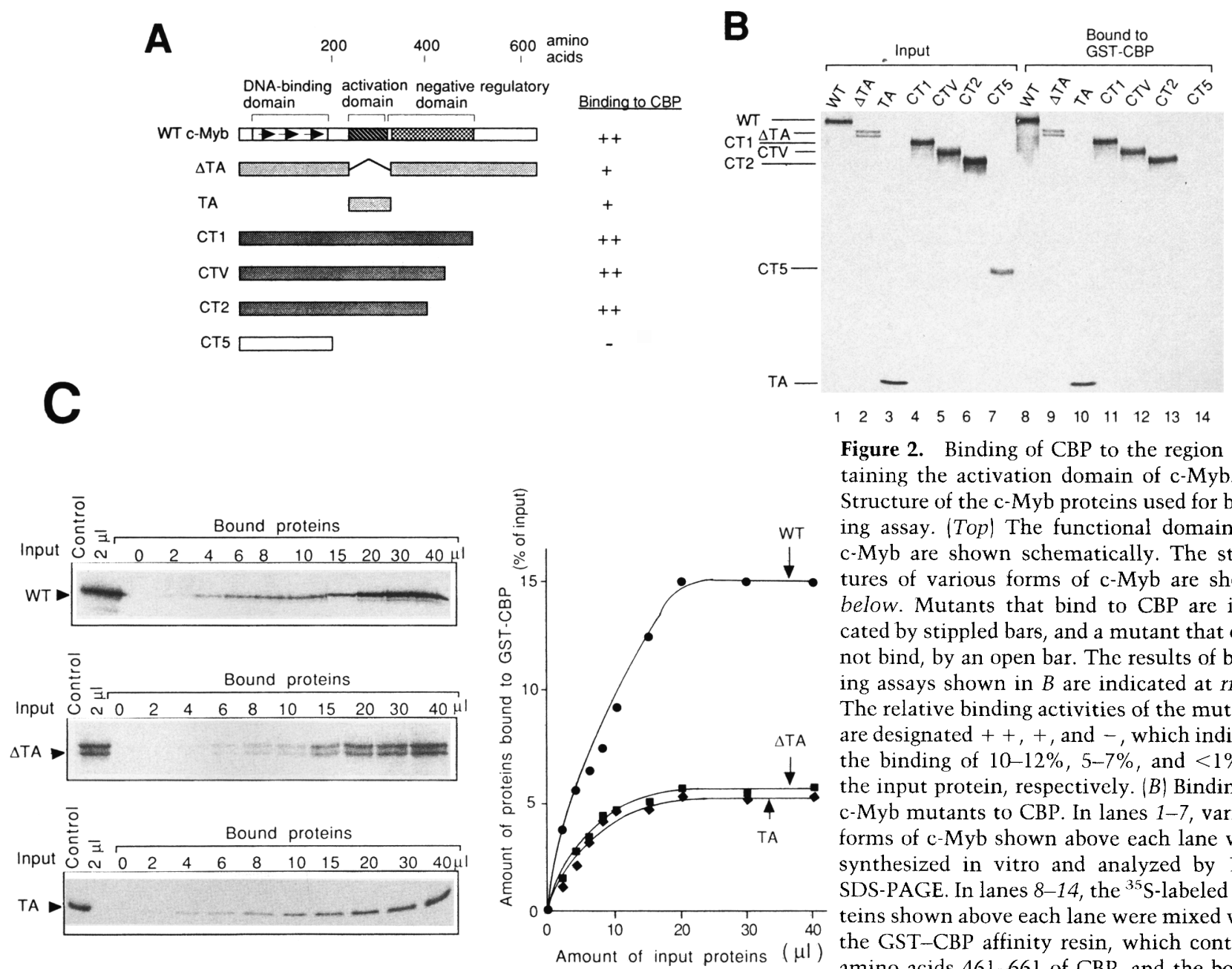

Figure 2. Binding of $\mathrm{CBP}$ to the region containing the activation domain of c-Myb. $|A|$ Structure of the c-Myb proteins used for binding assay. (Top) The functional domains of $\mathrm{c}-\mathrm{Myb}$ are shown schematically. The structures of various forms of $\mathrm{c}-\mathrm{Myb}$ are shown below. Mutants that bind to CBP are indicated by stippled bars, and a mutant that does not bind, by an open bar. The results of binding assays shown in $B$ are indicated at right. The relative binding activities of the mutants are designated,+++ , and - , which indicate the binding of $10-12 \%, 5-7 \%$, and $<1 \%$ of the input protein, respectively. $|B|$ Binding of c-Myb mutants to CBP. In lanes 1-7, various forms of c-Myb shown above each lane were synthesized in vitro and analyzed by $15 \%$ SDS-PAGE. In lanes $8-14$, the ${ }^{35}$ S-labeled proteins shown above each lane were mixed with the GST-CBP affinity resin, which contains amino acids 461-661 of CBP, and the bound proteins were analyzed on $15 \%$ SDS-PAGE followed by autoradiography. In lanes $1-7$, the amount of proteins was $10 \%$ of that used for binding assay. Less than $0.5 \%$ of the input c-Myb proteins bound to the control GST resin (data not shown). (C) Weaker binding of $\triangle T A$ and TA to CBP. To compare the binding affinities of wild-type c-Myb, $\triangle T A$, and TA mutants to CBP, increasing amounts of in vitro-translated c-Myb proteins were mixed with affinity resin containing $200 \mu \mathrm{g}$ of GST-CBP, and bound proteins were analyzed as described above. (Right) The amounts of the c-Myb proteins bound to GST-CBP are shown.

\section{In vivo binding of $c-M y b$ to $C B P$}

To examine the in vivo interaction between c-Myb and CBP, we used the yeast two-hybrid system. The Saccharomyces cerevisiae strain L40 used here contains two integrated reporter constructs, the yeast HIS3 gene and the bacterial lac $Z$ gene, which contain binding sites for the LexA protein (Vojtek et al. 1993). Four plasmids that encode the fusion proteins containing the VP16 activation domain and various portions of $\mathrm{c}-\mathrm{Myb}$ were constructed (211/360, CT2, CTY, and CT1) (Fig. 4A). All of these fusion proteins contained the domain interacting with $\mathrm{CBP}$, which was identified by the in vitro-binding assay shown in Figure 2. Expression in yeast L40 cells of any of these four fusion proteins together with the fusion protein consisting of the DNA-binding domain of the yeast transcription activator LexA (amino acids 1-211) and the CREB-binding domain of CBP (amino acids 461$682)$ led to the expression of the reporter gene HIS 3 and the growth of colonies on the plates lacking histidine (Fig. 4B). In the control experiments with the control plasmid encoding only the LexA DNA-binding domain, none of these four fusion proteins induced the expression of HIS3 and growth of colonies on the plates lacking histidine. In addition, the VP16 activation domain itself did not activate the expression of HIS3 when it was expressed with the LexA-CBP fusion protein. The interaction of c-Myb with CBP was also assessed by the ability to trans-activate the $l a c Z$ reporter construct (Fig. $4 \mathrm{C}$ ). The four VP16-c-Myb constructs (211/360, CT2, CTY, and CT1) produced 250-380 units of $\beta$-galactosidase activity when they were used with the LexA-CBP expression plasmid for transformation of yeast L40 cells. In contrast, the VP16 control vector lacking the c-Myb-coding region generated only the background level of activity (2-3 units) when it was used with the LexA-CBP expression plasmid or with the control plasmid pBTM for transformation. These results indicate that the region 


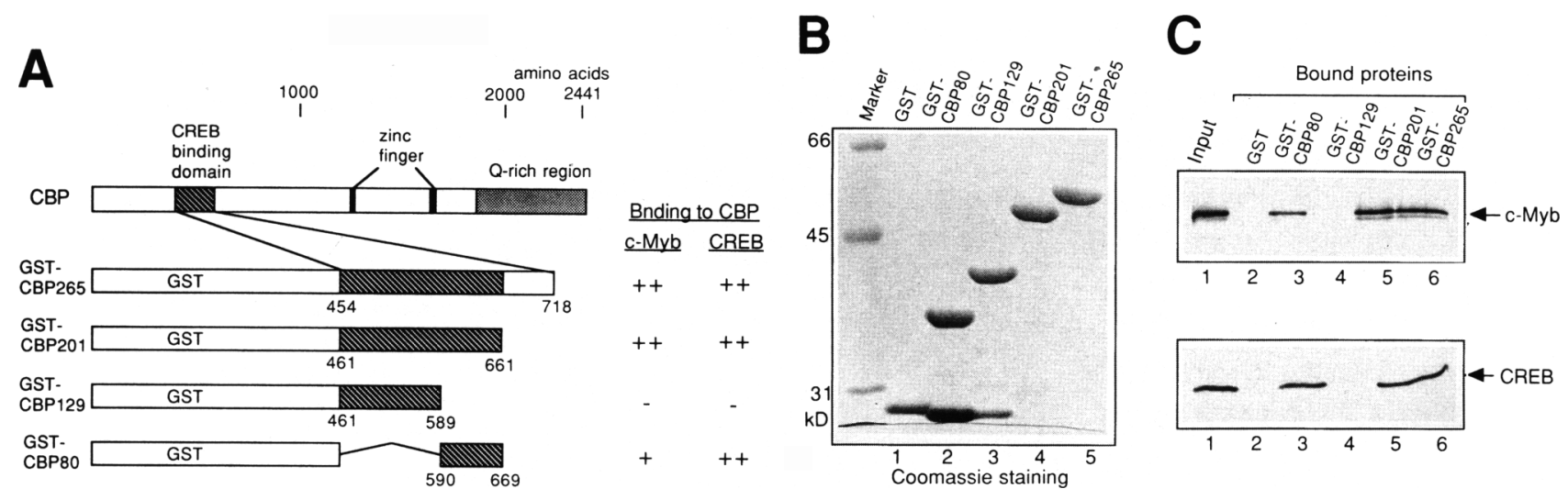

Figure 3. Domain of $\mathrm{CBP}$ required for binding to c-Myb. (A) Structure of the GST-CBP fusion proteins used for binding assay. (Top) The structure of murine CBP is shown schematically. The structures of four types of GST-CBP fusion proteins are shown below. The regions of CBP used for binding to $\mathrm{c}-\mathrm{Myb}$ in Fig. 1 are shown by hatched bars. The results of the binding assays shown in $B$ are indicated at right. The relative binding activities are designated,+++ , and - , which indicate the binding of $10 \%-14 \%, 5 \%-7 \%$, and $<1 \%$ of the input protein, respectively. $(B)$ Analysis of the GST-CBP fusion proteins. The bacterial lysates containing 3-5 $\mu \mathrm{g}$ of various GST-CBP fusion proteins or control GST were mixed with the glutathione-Sepharose resin and washed. The bound proteins were analyzed on 10\% SDS-PAGE followed by Coomassie brilliant blue staining. In lanes 2 and 3 , the GST protein that were generated by degradation of the fusion proteins is visible D
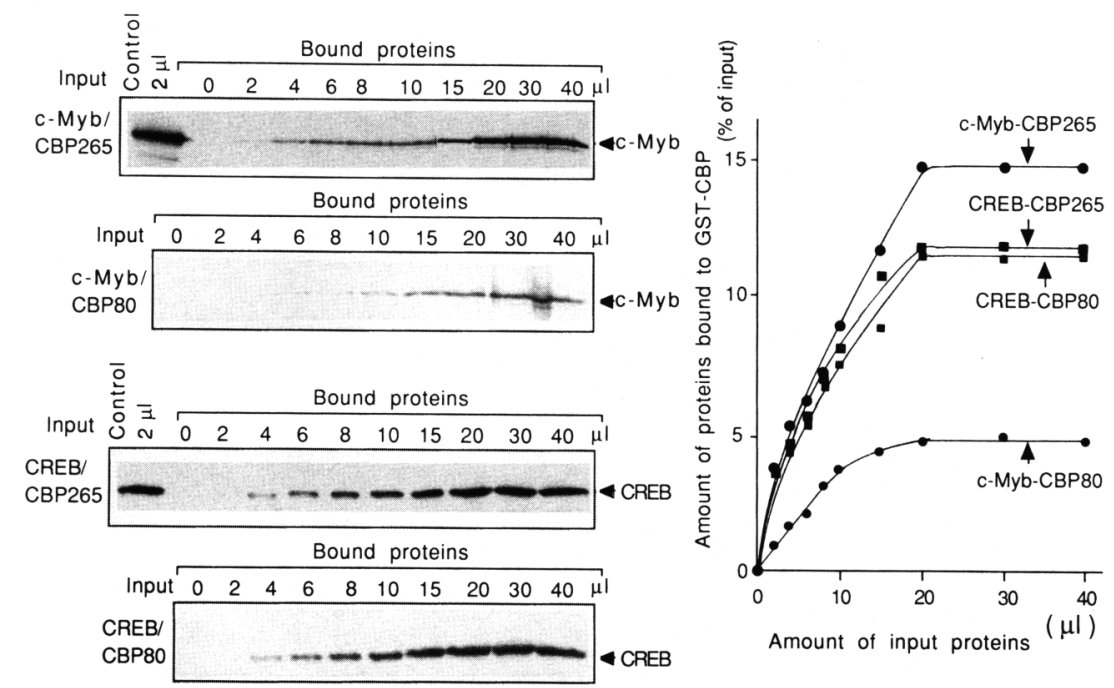

below. $(C)$ Binding of $\mathrm{c}-\mathrm{Myb}$ and CREB to four types of GST-CBP fusion proteins. The binding assays were performed using the affinity resin containing $200 \mu \mathrm{g}$ of each of the fusion proteins or control GST and shown as described in Fig. 1. The amount of c-Myb and CREB in lane 1 is $10 \%$ that used for binding assay. $(D)$ Comparison of the binding affinities using increasing amounts of in vitro-translated protein. To compare the binding affinities of $\mathrm{C}-\mathrm{Myb}$ or CREB to the 80 - and 201 -amino-acid regions of CBP, increasing amounts of in vitro-translated c-Myb or phosphorylated CREB proteins were mixed with the affinity resin containing $200 \mu \mathrm{g}$ of GST-CBP, and bound proteins were analyzed as described above. (Right) The amounts of c-Myb and CREB bound to GST-CBP are shown.

between amino acids 211 and 360 of c-Myb interacts with CBP in vivo.

\section{Coactivation of c-Myb-dependent gene expression by $C B P$}

To examine whether CBP functions as a coactivator of c-Myb, we then did some chloramphenicol acetyltransferese (CAT) cotransfection experiments using CV-1 cells (Fig. 5). The plasmid pA10CAT6MBS-I, which contains six tandem repeats of the Myb-binding site MBS-I linked to the SV40 early promoter, was used as a reporter. The CAT expression from this reporter plasmid is activated by c-Myb, and cotransfection of this reporter with $3 \mu \mathrm{g}$ of the c-Myb expression plasmid increased the level of CAT activity about four-fold in our standard as- say system (Nakagoshi et al. 1990; Nomura et al. 1993; Fig. 5 , cf. lanes 1 with or without c-Myb). As we reported previously (Nomura et al. 1993), 0.5-1 $\mu \mathrm{g}$ of the c-Myb expression plasmid DNA gives maximum trans-activation, and the degree of trans-activation decreases with additional increases in the amount of the c-Myb expression plasmid. Here we used $3 \mu \mathrm{g}$ of the $\mathrm{c}-\mathrm{Myb}$ expression plasmid because we expected that an excess of c-Myb would activate transcription by using CBP expressed from the CBP expression plasmid. Increasing amounts of the mouse CBP expression plasmid were cotransfected with this reporter in the presence or absence of $3 \mu \mathrm{g}$ of the c-Myb expression plasmid. Cotransfection of increasing amounts of the CBP expression plasmid increased the degree of trans-activation up to a maximum of 18 fold with $6 \mu \mathrm{g}$ of CBP expression plasmid in the presence of the c-Myb expression plasmid. In the control experi- 

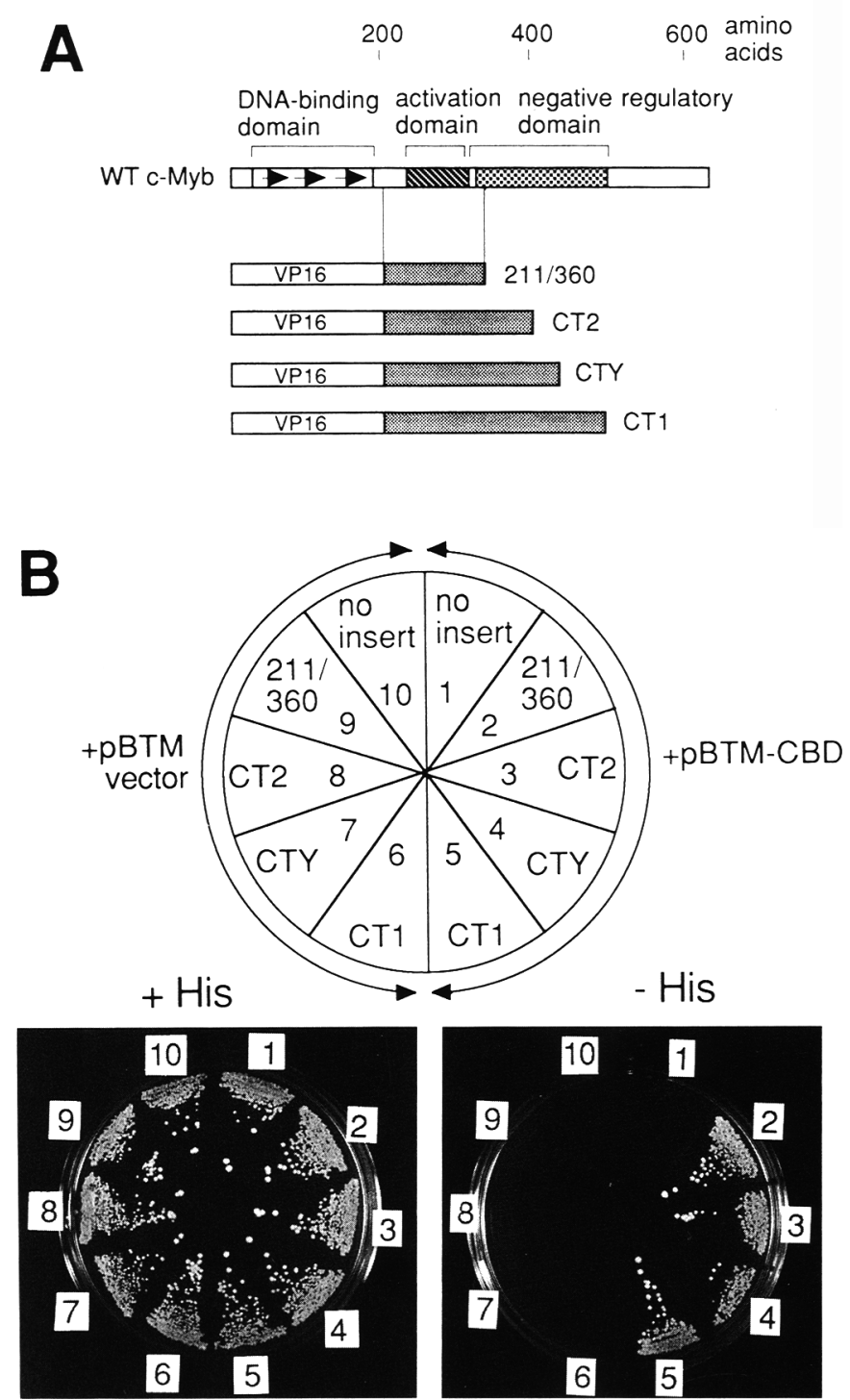

ment without any c-Myb expression plasmid, addition of the CBP expression plasmid did not affect the level of CAT activity at all. Thus, CBP potentiates c-Myb-induced trans-activation.

To confirm that CBP does not affect the level of $\mathrm{c}-\mathrm{Myb}$ expression from the transfected DNA, the levels of $\mathrm{c}-\mathrm{Myb}$ in the transfected cells were examined in the presence or absence of the CBP expression plasmid (Fig. 5B). Cell lysates were prepared from cells transfected wth a mixture of the c-Myb expression plasmid and the CBP expression plasmid or the control plasmid and used for Western blotting with the c-Myb-specific antibody. The level of c-Myb in the presence of the CBP expression plasmid was almost the same as that observed without the CBP expression plasmid.

We next asked whether CBP is required for the c-Mybdependent transcriptional activation by using the plas-

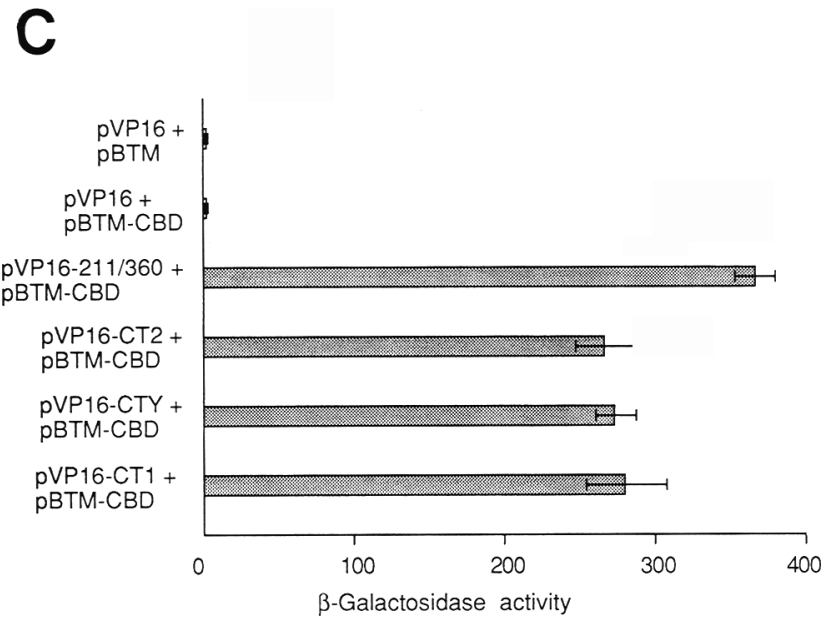

Figure 4. In vivo interactions of $\mathrm{c}-\mathrm{Myb}$ and CBP. (A) Structure of the VP16-c-Myb fusion proteins used for yeast two-hybrid assay. (Top) The functional domains of $\mathrm{c}-\mathrm{Myb}$ are shown schematically. The structures of various forms of VP16-c-Myb fusion proteins are shown below. 211/360, CT2, CTY, and CT1 contain the amino acids 211-360, 211-400, 211-460, and 211-500 of c-Myb, respectively. $(B)$ Assay of HIS3 reporter construct. The $S$. cerevisiae reporter strain L40 was transformed with the pBTMCBD plasmid encoding the fusion protein, which consists of the LexA DNA-binding domain (amino acids 1-211) and the CREBbinding domain of CBP \{amino acids 461-682\}, and the plasmid to express the indicated VP16-c-Myb fusion protein (1-5). In the control experiments $|6-10|$, L40 was transformed with the pBTM vector encoding only the LexA DNA-binding domain and the plasmid to express the indicated VP16-c-Myb fusion protein. Individual $\mathrm{Leu}^{+} \operatorname{Trp}^{+}$transformants were streaked on synthetic medium plates lacking tryptophan, histidine, leucine, uracil, and lysine (- His) but including $15 \mathrm{~mm} 3$-aminotriazole and on synthetic medium plates lacking leucine and tryptophan (+ His) but containing $15 \mathrm{~mm} 3$-aminotriazole. The plates were incubated at $30^{\circ} \mathrm{C}$ for 3 days. $|C| \beta$-Galactosidase activity from the $l a c Z$ reporter construct. Three independent transformants harboring the plasmids indicated at left were isolated and grown, and their $\beta$-galactosidase activities were measured. Values shown are the averages of duplicate assays of three independent transformants with the standard deviation indicated.

mid to express the antisense RNA of mouse CBP (Fig. 6A). Expression of the antisense RNA in mouse NIH-3T3 cells can be expected to block the synthesis of endogenous CBP. Increasing amounts of the antisense CBP RNA expression plasmid were cotransfected with the reporter plasmid pA10CAT6MBS-I in the presence or absence of the $c-M y b$ expression plasmid. The antisense CBP RNA inhibited the c-Myb-dependent transcriptional activation in a dose-dependent manner but did not affect the basal promoter activity of the reporter plasmid in the absence of c-Myb. Western blot analysis of the level of $c-M y b$ in the transfected cells indicated that the antisense CBP RNA expression plasmid did not affect the c-Myb expression from the transfected c-Myb expression plasmid (Fig. 6B). These results suggest that endogenous CBP is required for $\mathrm{C}-\mathrm{Myb}$-induced transcriptional activation. 
Dai et al.

Figure 5. Effects of CBP on c-Myb-dependent transcriptional activation. $(A)$ Potentiation of c-Myb-activated gene expression by CBP. A mixture of $0,1,2,3,4,5$, or $6 \mu \mathrm{g}$ (lanes 1-7) of the CBP expression plasmid $\mathrm{pRc} / \mathrm{RSV}-\mathrm{CBP}, 4 \mu \mathrm{g}$ of a CAT reporter plasmid pA10CAT6MBS-I, $3 \mu \mathrm{g}$ of the c-Myb expression plasmid pact-c-myb (top) or the control plasmid pact-1 (bottom) lacking the $c-M y b$-coding region, and $1 \mu \mathrm{g}$ of the internal control plasmid pact- $\beta$-gal was transfected into CV-1 cells. The total amount of DNA was adjusted to $14 \mu \mathrm{g}$ by adding the control plasmid pRSV0 lacking the CBPcoding region. CAT assays were done as described in Materials and methods. A typical result is shown at left. The degree of transactivation /compared to samples without the c-Myb expression plasmid) shown at right is the average of three independent experiments with standard deviations indicated. $(B)$ Effects of $\mathrm{CBP}$ on the expression of $\mathrm{c}-\mathrm{Myb}$ in transfected cells. CV-1 cells were transfected with a mixture of $6 \mu \mathrm{g}$ of the CBP expression plasmid pRc/RSV-CBP $1+$ ) or the control plasmid pRc/RSV0 $1-1,4$ $\mu \mathrm{g}$ of the CAT reporter plasmid pA10CAT6MBS-I, $3 \mu \mathrm{g}$ of the c-Myb expres. sion plasmid pact-c-myb, and $1 \mu \mathrm{g}$ of the internal control plasmid pact- $\beta$-gal. Proteins were prepared from the transfected cells and separated by SDS-PAGE on a $10 \%$ gel. The $\mathrm{c}-\mathrm{Myb}$ proteins were detected by Western blot analysis. The precise amounts of lysates used for Western blotting were normalized with respect to $\beta$-galactosidase activity. Lanes 1 and 2 contain the proteins from $\sim 2 \times 10^{6}$ cells. The amount of proteins in lanes 3 and 4 , and lanes 5 and 6 is $1 / 2$ and $1 / 4$, respectively, of the amount in lanes 1 and 2.

Figure 6. Inhibition of c-Myb-induced transcriptional activation by expression of the antisense CBP RNA. (A) Repression of $\mathrm{c}$-Myb-dependent gene expression by antisense CBP RNA. A mixture of 0, 2, 4, 6, 8, or $10 \mu \mathrm{g}$ (lanes 1-6) of the antisense CBP RNA expression plasmid pSR $\alpha$-anti$\mathrm{CBP}, 4 \mu \mathrm{g}$ of a CAT reporter plasmid pA10CAT6MBS-I, $3 \mu \mathrm{g}$ of the c-Myb expression plasmid pact-c-myb (top) or the control plasmid pact-1 (bottom) lacking the $\mathrm{c}-\mathrm{Myb}$-coding region, and $\mathrm{l} \mu \mathrm{g}$ of the internal control plasmid pact- $\beta$-gal was transfected into NIH-3T3 cells. The total amount of DNA was adjusted to $14 \mu \mathrm{g}$ by adding the control plasmid pRSV0 lacking the CBP-coding region. CAT assays were done as described in Materials and methods. The results are as shown in Fig. 5. (B) Effects of antisense CBP RNA on the expression of c-Myb in transfected cells. NIH3 T3 cells were transfected with a mixture of $6 \mu \mathrm{g}$ of the antisense CBP RNA expression plasmid pSR $\alpha$-anti-CBP $(+)$ or the control plasmid pRc/RSVO $(-1,4 \mu \mathrm{g}$ of the CAT reporter plasmid pA10CAT6MBS-I, 3 $\mu \mathrm{g}$ of the $\mathrm{c}-\mathrm{Myb}$ expression plasmid pact-c$m y b$, and $1 \mu \mathrm{g}$ of the internal control plasmid pact- $\beta$-gal. Western blotting was performed, and the results are as shown in Fig. 5.
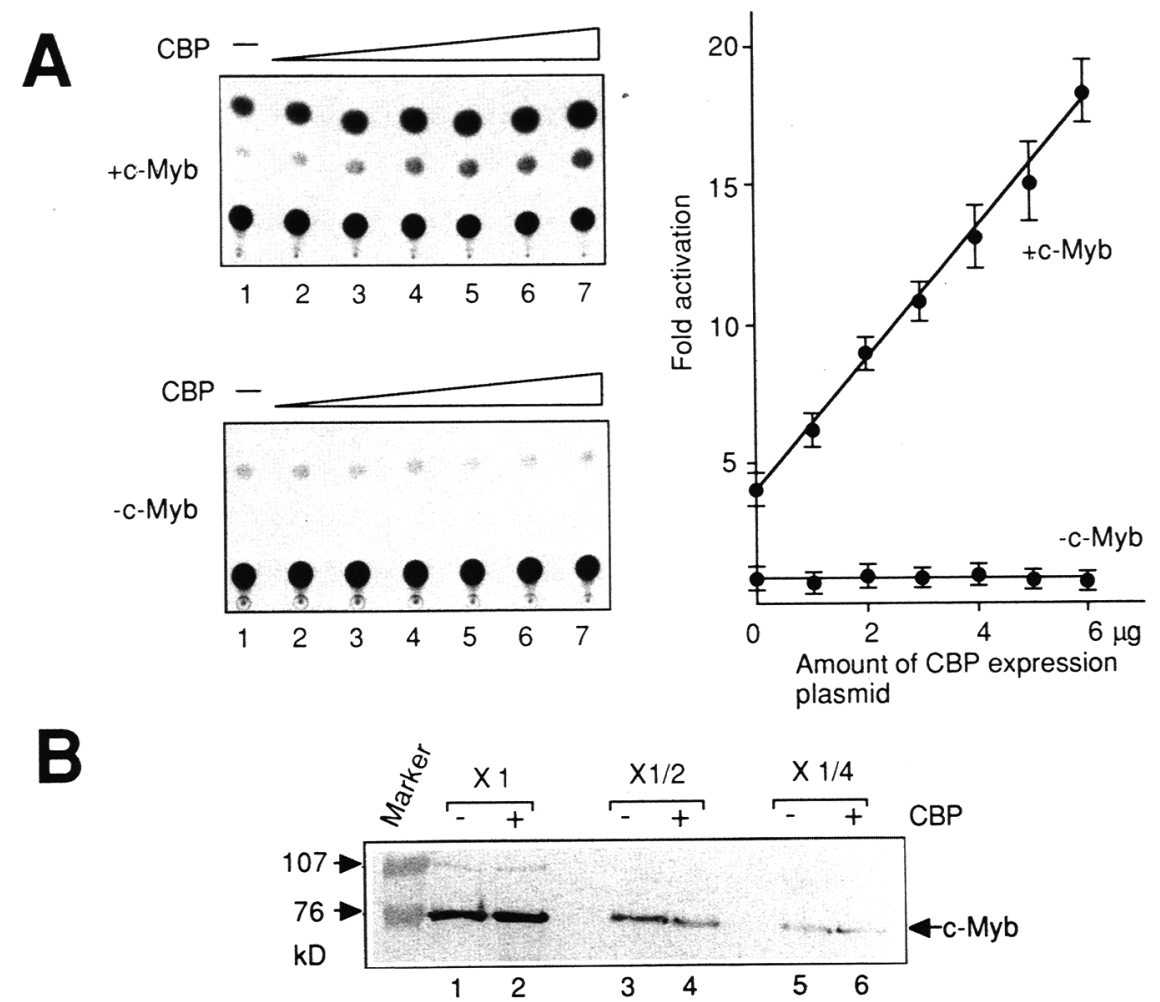

A
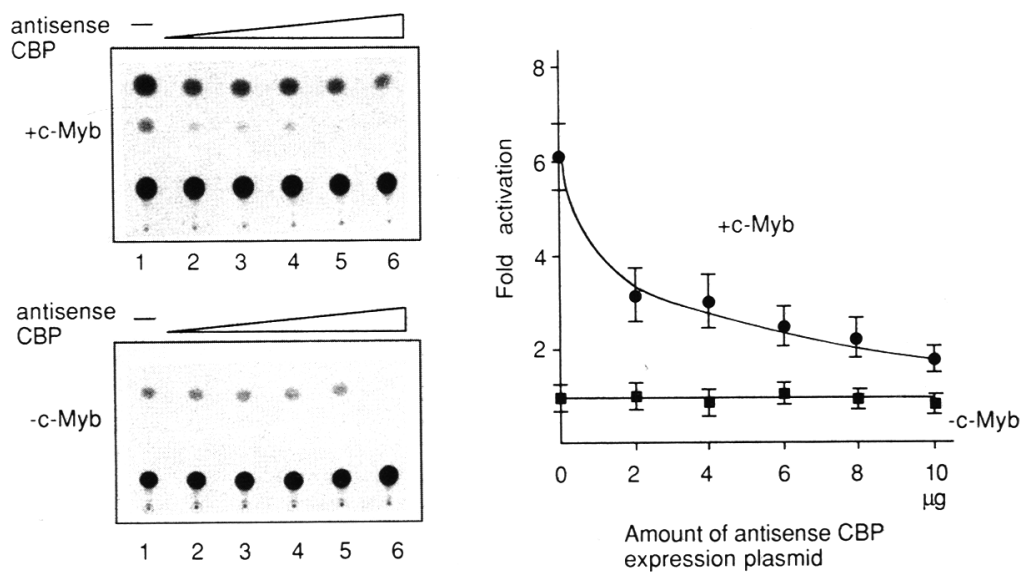

B

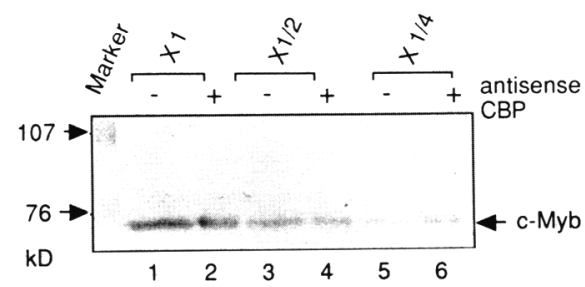


Effects of E1A on c-Myb-induced transcriptional activation

E1A binds to CBP and inhibits CREB-dependent transcriptional activation (Arany et al. 1995; Lundblad et al. 1995). We therefore examined the effects of ElA on c-Myb-induced transcriptional activation (Fig. 7). Here we used $1 \mu \mathrm{g}$ of the $\mathrm{c}$-Myb expression plasmid to observe the maximum trans-activation by $\mathrm{c}-\mathrm{Myb}$. Cotransfection of the reporter plasmid pA10CAT6MBS-I with the E1A $12 S$ expression plasmid did not affect the basal level of CAT activity (lanes 1-4). However, in the presence of the c-Myb expression plasmid, E1A 12S decreased the level of CAT activity in a dose-dependent manner (lanes $5-8)$. As a control, two E1A mutants, $\Delta 30-85$ and $\Delta 121-$
150, were also used. It had been demonstrated that CBP and E1A interact in vivo with the same specificity as do p300 and E1A (Arany et al. 1995; Lundblad et al. 1995). $\Delta 30-85$ is known neither to interact efficiently with p300 (Whyte et al. 1989) nor to block p300-dependent trans-activation, but $\Delta 121-150$, which is unable to interact with any retinoblastoma family protein (Stein et al. 1990), interacts with p300 and inhibits p300-dependent trans-activation. As shown in Figure 7, c-Myb-induced transcriptional activation was blocked by $\Delta 121-$ 150 (lanes $17-24$ ) but not by $\Delta 30-85$ (lanes 9-16). Thus, the repression by E1A $12 \mathrm{~S}$ is specific and depends on the ability of E1A to interact with $\mathrm{CBP} / \mathrm{p} 300$. When we also added the CBP expression plasmid, the inhibition of c-Myb-induced transcriptional activation by E1A $12 S$

A
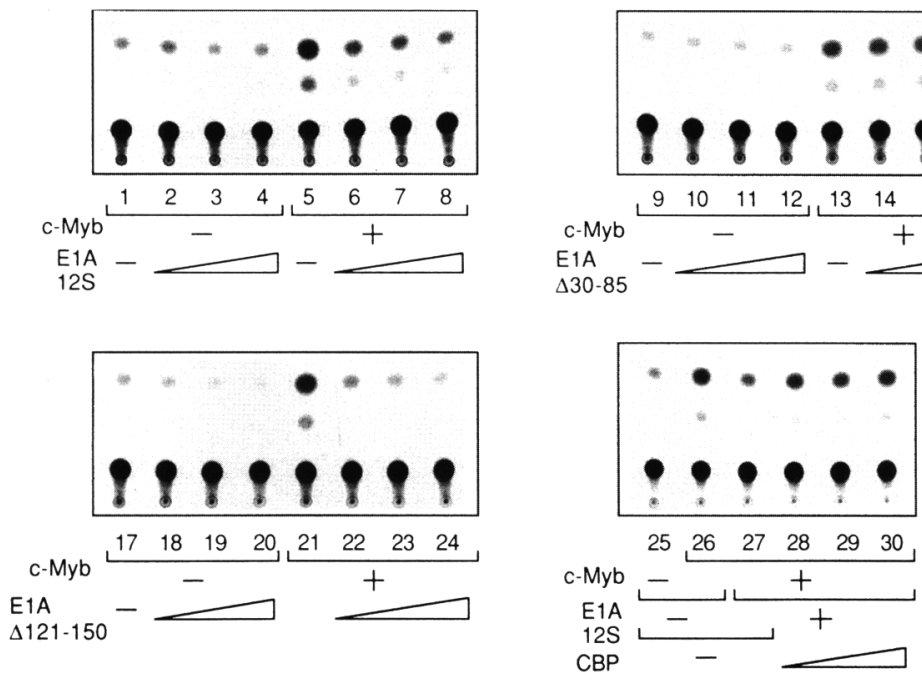

B

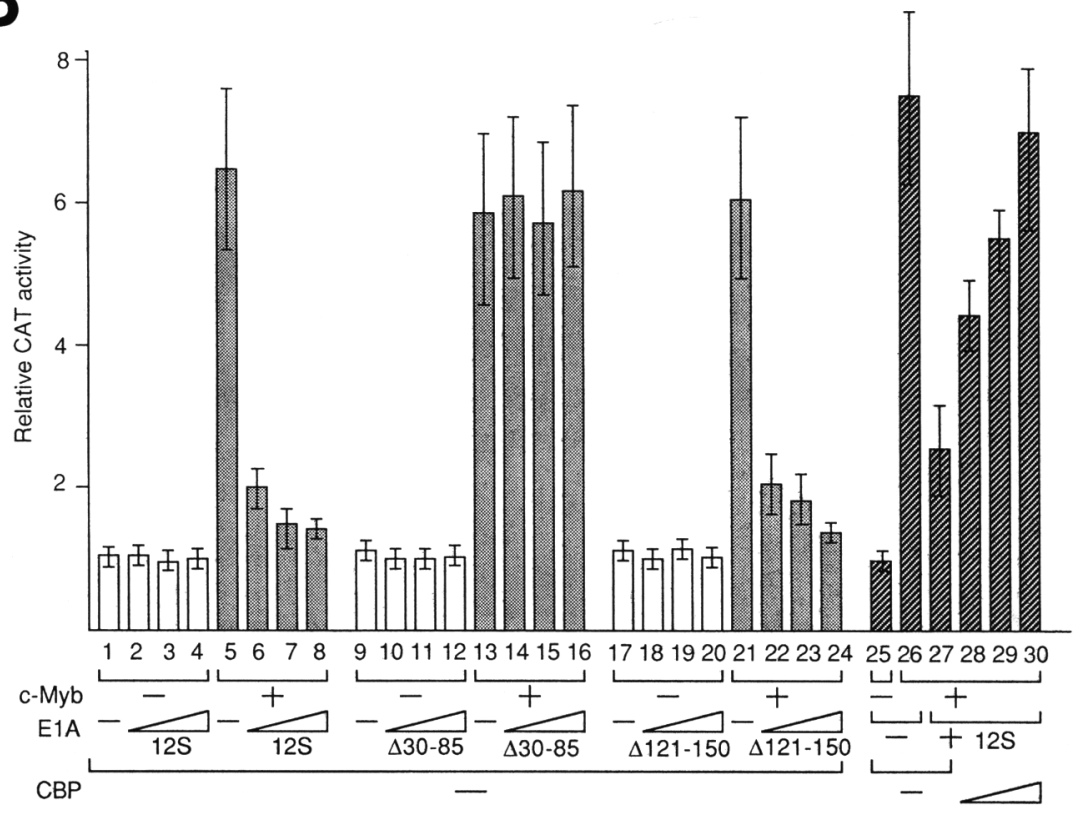

Figure 7. Repression of c-Myb-dependent transcriptional activation by E1A. $(A)$ Typical result of CAT assay. In the experiments (lanes 1-24) examining the effects of three forms of E1A on c-Myb-dependent gene expression, a mixture of $4 \mu \mathrm{g}$ of the reporter plasmid pA10CAT6MBS-I, $1 \mu \mathrm{g}$ of the c-Myb expression plasmid pact-c-myb $(+)$ or the control plasmid pact- $1(-), 0$ (lanes $1,5,9,13,17,21$ ), 2 (lanes 2,6,10,14,18,22), 4 (lanes 3,7,11,15,19,23), or 6 (lanes $4,8,12,16,20,24) \mu \mathrm{g}$ of the E1A $12 \mathrm{~S}$ (lanes $1-8$ ), $\Delta 30-85$ (lanes $90-16$ ), or $\Delta 121-150$ (lanes 17-24) expression plasmid, and $1 \mu \mathrm{g}$ of the internal control plasmid pact- $\beta$-gal was transfected into CV-1 cells. The total amount of DNA was adjusted to $12 \mu \mathrm{g}$ with the control plasmid $\mathrm{pE} 1 \mathrm{~A}^{-}$(lanes $\left.1-8\right)$ or pCMV0 lacking the E1A-coding region (lanes 9-24). In the experiments examining the effects of CBP on the repression of the c-Myb-induced transcription by E1A flanes 25-301, a mixture of $4 \mu \mathrm{g}$ of the reporter plasmid pA10CAT6MBS-I, $1 \mu \mathrm{g}$ of the c-Myb expression plasmid pact-c-myb $1+1$ or the control plasmid pact-1 $(-1,2 \mu \mathrm{g}$ of E1A $12 S$ expression plasmid $(+)$ or the control plasmid pE1A $-(-1,0$ (lanes 25-27), 6 (lane 28), 10 (lane 29), or 14 (lane 30) $\mu \mathrm{g}$ of the CBP expression plasmid $\operatorname{pSR} \alpha-\mathrm{CBP}$ DNA, and $1 \mu \mathrm{g}$ of the internal control plasmid pact- $\beta$-gal was transfected into $\mathrm{CV}-1$ cells. The total amount of DNA was adjusted to $22 \mu \mathrm{g}$ with the control plasmid $\mathrm{pE} \mathrm{A}^{-}$lacking the E1A-coding region and pSR $\alpha 0$ lacking the CBP-coding region (lanes 9-24). (B) The results of three independent experiments. The average of three experiments are shown as relative CAT activity with standard deviations indicated. 
was abolished (lanes $25-30$ ). These results indicate that E1A suppresses c-Myb-dependent transcriptional activation and repression by E1A is mediated by CBP.

\section{Discussion}

Our results indicate that CBP binds to the region containing the activation domain of $\mathrm{c}-\mathrm{Myb}$ and functions as a coactivator of $\mathrm{c}-\mathrm{Myb}$. CBP binds to phosphorylated CREB, but not to the nonphosphorylated form. In contrast, in vitro-translated c-Myb bound to GST-CBP without phosphorylation by PKA. This result was confirmed by phosphatase treatment of in vitro-translated c-Myb and the experiment with the bacterially expressed c-Myb: Recombinant c-Myb also bound efficiently to CBP without any phosphorylation. These results indicate that CBP binds to nonphosphorylated c-Myb, although we cannot exclude the possibility that phosphorylation of $c-M y b$ by some kinase increases the efficiency of binding to CBP. Recently, CBP has been suggested to be a coactivator specific to a group of phosphorylated activators, including CREB, Jun, and SRF (Arias et al. 1994). Our results indicate that CBP is a coactivator not only for phosphorylated CREB but also for nonphosphorylated transcription activators such as c-Myb. During preparation of this paper Bannister and Kouzarides (1995) reported that CBP also binds to c-Fos in a phosphorylation-independent manner and functions as a coactivator for c-Fos. However, c-Fos binds to the carboxy-terminal domain of CBP, which is also used to contact E1A, and this Fos-binding domain is different from the c-Myb- or CREB-binding domain. In addition, Lee et al. (1995) reported that the CBP-related protein p300 binds to the transcriptional repressor YY1, a human glioblastoma-Krüppel-related protein (Shi et al. 1991), and that binding of E1A to p300 relieves transcriptional repression by YY1. In this case, CBP also binds to nonphosphorylated YY1. Therefore, CBP binds to the transcriptional activators CREB, c-Fos, c-Myb, and the repressor YY1. Thus, CBP may function as a coactivator for more enhancer-binding factors than expected previously.

Our results indicate that the 80 -amino-acid region of CBP (amino acids 590-669) is sufficient for binding to phosphorylated CREB and necessary for binding to c-Myb. Thus, CREB and c-Myb appear to bind to the same region of CBP. Interestingly, mutations in the human CBP gene cause Rubinstein-Taybi syndrome through haploinsufficiency (Petrij et al. 1995), suggesting that the amount of CBP in cells is not excessive and a $50 \%$ decrease in the amount affects normal development. Transfection of only $2 \mu \mathrm{g}$ of the plasmid to express antisense CBP RNA resulted in a 50\% decrease in transactivation by c-Myb (Fig. 6A). These results may also be consistent with this speculation. Thus, cross talk between the c-Myb and CAMP pathway through competition with phosphorylated CREB for binding to CBP is possible. Therefore, it is important to examine whether c-Myb activity is inhibited by activation of the cAMP pathway. Although YYl and c-Fos bind to different domains of CBP or p300 from c-Myb and CREB, we cannot exclude the possibility that the YY1- and/or c-Fos-interacting domain is also necessary to mediate c-Myb- and CREB-induced transcriptional activation. In this context, it is also of interest whether c-Myb affects not only the CREB- but also the AP-1-, or YY1-dependent transcriptional regulation by competing for binding to CBP.

To bind to CBP efficiently, the region between amino acids 194 and 401 of c-Myb is necessary, and the transcriptional activation domain identified previously (amino acids 238-325) containing the acidic amino acidrich region binds to $\mathrm{CBP}$ with lower efficiency. These results suggest that $C B P$ binds to multiple regions, including the acidic amino acid cluster in the activation domain of c-Myb. Thus far, the presence of multiple subdomains in the carboxy-terminal half of c-Myb that negatively regulate the c-Myb activity was reported /Sakura et al. 1989; Kalkbrenner et al. 1990; Dubendorff et al. 1992; Kanei-Ishii et al. 1992). Although the mechanism of negative regulation of c-Myb activity by these subdomains is unclear, some of them were suggested to modulate transcriptional activation, not DNA binding. Analyses of the effects of these subdomains on binding to CBP may lead to understanding the role of these subdomains.

Among the three members of the mammalian c-myb gene family, A-Myb and c-Myb function as a transcriptional activator in all cells examined, but the transcriptional activating capacity of B-Myb depends on the cell type (Takahashi et al. 1995: Tashiro et al. 1995). B-Myb activates transcription through binding to the Myb-binding site, MBS-I, in CV-1 cells but not in NIH-3T3 cells. It was suggested that the putative cofactor that binds to the carboxy-terminal region in B-Myb is required for cell type-specific trans-activation by B-Myb. Although it is not known whether CBP binds to B-Myb, the interesting possibility is that this putative cofactor supports the interaction between CBP and B-Myb.

E1A can down-regulate transcriptional activation mediated by c-Myb. This result is similar to the recent report that E1A can repress CREB- and c-Fos-induced transcriptional activation (Arany et al. 1995; Bannister and Kouzarides 1995; Lundblad et al. 1995). Because the growth-inhibitory and differentiation-inducing effects of cAMP are well documented, the ability of E1A to interfere with the cAMP pathway through CBP could be important for cell immortalization by ElA. However, $\mathrm{c}-\mathrm{Myb}$ and c-Fos are positive regulators of proliferation, so that the block of the c-Myb- or c-Fos-induced transcriptional activation by E1A appears not to be consistent with the view that E1A-induced cell immortalization may depend on interactions between ElA and CBP. One idea to resolve this discrepancy is that $\mathrm{c}-\mathrm{Myb}$ and c-Fos are implicated in both the proliferative and differentiation pathways and that E1A preferentially blocks the differentiation-specific transcription induced by $c-M y b$ and c-Fos. Interestingly, it was postulated that the promoters of proliferation genes regulated by c-Myb possess Myb-binding sites with higher affinity or greater 
number than do differentiation genes (Dini and Lipsick 1993). It is of interest whether E1A leads to preferential inhibition of the activity of promoters to which $\mathrm{c}-\mathrm{Myb}$ binds weakly by partly repressing the function of CBP. Analyses of the effect of CBP or antisense CBP RNA expression plasmid on the c-Myb-induced trans-activation of various promoters may contribute to examination of this possibility.

\section{Materials and methods}

\section{Plasmids}

To express various forms of GST-CBP fusion proteins in E. coli, the plasmids pGST-CBP265, pGST-CBP201, pGST-CBP129, and pGST-CBP80 were made by inserting the BamHI-EcoRI fragment encoding the regions of 265 (amino acids 454-718), 201 (amino acids 461-661), 129 (amino acids 461-589), and 80amino-acids (amino acids 590-669) of mouse CBP, respectively, which was prepared by PCR, into the BamHI-EcoRI site of the pGEX-4T-3 vector (Smith and Johnson 1988; Pharmacia). The modified pSP65 vector pSPUTK (Stratagene) was used for in vitro transcription/translation of various forms of $\mathrm{c}-\mathrm{Myb}$, except for the $\Delta$ TA mutant. This vector contains the Xenopus $\beta$-globin 5'-untranslated region and the consensus Kozak translation initiation site. To generate the plasmids to express various forms of $\mathrm{c}-\mathrm{Myb}$, the NcoI-Xbal fragment containing the $c-M y b$-coding region was prepared from the actin promoterbased expression plasmids and inserted into the $\mathrm{NcoI}-\mathrm{XbaI}$ site of pSPUTK. To construct the plasmid pSPUTKmybTA, which was used to synthesize in vitro the TA protein containing only the activation domain of $\mathrm{c}-\mathrm{Myb}$, the $\mathrm{NcoI}-\mathrm{BamHI}$ fragment containing the region between amino acids 243 and 325 of c-Myb was prepared by a PCR-based method (Higuchi 1990). This fragment was inserted into the NcoI-BamHI site of pSPUTK. The plasmid pSP65NcoImyb $\Delta \mathrm{TA}$, expressing the c-Myb $\triangle T A$ mutant in the in vitro transcription/translation system, was constructed by inserting the $\mathrm{NcOI}-\mathrm{XbaI}$ fragment containing the c-Myb-coding region into the $\mathrm{NcoI}-\mathrm{XbaI}$ site of the modified pSP65 vector pSP65NcoI, which has an NcoI site at the original SmaI site.

The plasmids expressing c-Myb in cultured cells have been described (Sakura et al. 1989). The pAl0CAT6MBS-I reporter plasmid containing tandem repeats of the Myb-binding site, the control effector plasmid pact-1, and the internal control plasmid pact- $\beta$-gal were also described previously (Nakagoshi et al. 1990; Maekawa et al. 1991a). The CBP expression plasmid pRc/ RSV-CBP (Chrivia et al. 1993) and the CREB expression plasmid pRSV-CREB (Gonzalez and Montminy 1989) were kindly provided by Drs. R.H. Goodman (Vollum Institute, Oregon Health Sciences University, Portland) and M.R. Montminy (Salk Institute, La Jolla, CA), respectively. The plasmids expressing CBP or antisense CBP RNA, $\mathrm{pSR} \alpha-\mathrm{CBP}$, or $\mathrm{pSR} \alpha$-antiCBP were constructed by transfer of the BamHI CBP cDNA insert of pRc/RSV-CBP into the EcoRI site of the SR $\alpha$ promoter construct in either direction after converting both sites into flush ends (Takebe et al. 1988). The ElA expression plasmid pE1A12S and the control plasmid lacking the E1A-coding region (Leff et al. 1984) were kindly donated by Dr. C. Kedinger. The plasmids to express E1A mutants $\Delta 30-85$ and $\Delta 121-150$ are gifts from Dr. R. Eckner /The Dana Farber Cancer Institute and Harvard Medical School, Boston, MA).

The plasmid $\mathrm{pBTM}-\mathrm{CBD}$, expressing in yeast cells a fusion protein consisting of the LexA DNA-binding domain lamino acids 1-211) and the CREB-binding domain of CBP (amino acids
461-6821, was a gift from Dr. R.H. Goodman. The parental vector pBTM116 for pBTM-CBP was described by Vojtek et al. (1993). The four plasmids expressing the fusion proteins consisting of the VP16 activation domain and various portions of c-Myb were constructed as follows using the plasmid pVP16, which was also described by Vojtek et al. (1993). The BamHINotI fragment encoding the amino acids $211-360$ of c-Myb was prepared by PCR and inserted into the BamHI-NotI cloning site of pVP16 to generate the plasmid pVP16-211/360. To construct the three other plasmids, pVP16-CT2, pVP16-CTY, and pVP16-CT1, the SphI-BamHI fragments encoding the carboxyterminal half of the $\mathrm{c}-\mathrm{Myb}$-coding region were prepared from the $\beta$-actin promoter-based expression plasmids for CT2, CTY, and CTl (Sakura et al. 1989; Hu et al. 1991), and the SphI-NotI fragment of pVP16-211/360 was replaced by either of these fragments after converting the BamHI and NotI sites into flush ends. These three plasmids encode amino acids 211-400, 211460 , and 211-500 of c-Myb, respectively.

\section{In vitro-binding analysis with GST fusion proteins}

Expression of the GST-CBP fusion protein or GST in E. coli and preparation of the bacterial lysates containing these proteins were done as described (Nomura et al. 1993). Samples of bacterial lysate containing $200 \mu \mathrm{g}$ of GST or GST-CBP were rocked for $2 \mathrm{hr}$ at $4^{\circ} \mathrm{C}$ with $80 \mu \mathrm{l}$ of glutathione-Sepharose beads (Pharmacia). The beads were washed five times with $1 \mathrm{ml}$ of PBS and then with $1 \mathrm{ml}$ of binding buffer [20 mM HEPES (pH 7.7), $75 \mathrm{~mm}$ $\mathrm{KCl}, 0.1 \mathrm{~mm}$ EDTA, $2.5 \mathrm{~mm} \mathrm{MgCl}_{2}, 1 \%$ skim milk, $1 \mathrm{~mm}$ DTT, $0.05 \%$ NP-40]. Various forms of c-Myb were synthesized with $\left[{ }^{35} \mathrm{~S}\right]$ methionine using an in vitro transcription/translation kit according to the procedures described by the supplier (Promega). Then, $20 \mu l$ of reaction was mixed with $1.5 \mathrm{ml}$ of binding buffer and GST or GST-CBP affinity resin. After rocking at $4^{\circ} \mathrm{C}$ for 2 $\mathrm{hr}$, the resin was washed five times with $1 \mathrm{ml}$ of PBS and mixed with SDS-sample buffer, and the bound proteins were released by boiling. The proteins were analyzed by SDS-PAGE followed by autoradiography. In experiments examining the effects of phosphorylation by PKA, $50 \mu \mathrm{l}$ of lysate containing in vitrotranslated c-Myb or CREB was mixed with $150 \mu$ l of the kinase buffer to adjust to a final concentration of $20 \mathrm{~mm}$ Tris- $\mathrm{HCl} / \mathrm{pH}$ 7.5 ), $100 \mathrm{mM} \mathrm{NaCl}, 12 \mathrm{mM} \mathrm{MgCl}_{2}$, and $2.5 \mathrm{~mm}$ ATP and incubated with or without 100 units of the catalytic subunit of bovine protein kinase A (Sigma). In experiments examining the effects of phosphatase, $20 \mu \mathrm{l}$ of lysates containing ${ }^{35}$ S-labeled c-Myb was incubated with or without 10 units of potato acid phosphatase (Sigma) in $500 \mu \mathrm{l}$ of the phosphatase buffer [10 $\mathrm{mm}$ Tris- $\mathrm{HCl}$ (pH 7.5), $50 \mathrm{~mm} \mathrm{KCl,} 1 \mathrm{~mm}$ DTT, 0.05\% NP-40, 100 $\mu \mathrm{g} / \mathrm{ml}$ of bovine serum albumin (BSA), and $5 \%$ glycerol]. To examine the interaction of bacterially expressed $\mathrm{c}-\mathrm{Myb}$ and $\mathrm{CBP}$, full-length c-Myb was expressed as a soluble form using our newly developed $E$. coli expression system, in which many mammalian proteins were expressed as soluble forms by coexpression of the bacterial thioredoxin (Yasukawa et al. 1995). The bacterial lysates containing the soluble form of c-Myb was prepared using buffer $\mathrm{M}[50 \mathrm{mM}$ Tris- $\mathrm{HCl}(\mathrm{pH} 8.0), 0.5 \mathrm{mM}$ EDTA, $10 \mathrm{mM}$ DTT, $125 \mathrm{mM}$ PMSF], similarly to the case of GST-CBP fusion proteins, and then passed through DEAE-cellulose. The flowthrough fraction containing $\mathrm{c}-\mathrm{Myb}$ was used for binding analysis. The binding assays with the bacterially made $c-M y b$ were done similarly.

In vivo interaction analysis using the yeast two-hybrid system

Yeast two-hybrid assays were performed using a modified version (Vojtek et al. 1993) of the system developed by Fields and 
Song (1989). The genotype of the $S$. cerevisiae reporter strain L40 was described by Vojtek et al. (1993). The S. cerevisiae L40 reporter strain was transformed with two kinds of plasmids encoding the LexA-CBP fusion protein or the c-Myb-VP16 fusion protein. Transformants were plated on a synthetic medium lacking leucine, tryptophan, and uracil. The plates were incubated at $30^{\circ} \mathrm{C}$ for 3 days. Individual Leu ${ }^{+} \mathrm{Trp}^{+}$transformants were picked up and streaked on synthetic medium plates lacking tryptophan, histidine, leucine, uracil, and lysine but including $15 \mathrm{~mm} 3$-aminotriazole, a chemical inhibitor of imidazole glycerol phosphate dehydratase which restores histidine auxotrophy (Durfee et al. 1993), and on control synthetic medium plates lacking leucine, tryptophan, and uracil but containing 15 $\mathrm{mM} 3$-aminotriazole. The plates were incubated at $30^{\circ} \mathrm{C}$ for 3 days. To measure $\beta$-galactosidase activity, three independent transformants grown in synthetic control medium lacking leucine, tryptophan, and uracil were isolated and grown at $30^{\circ} \mathrm{C}$ until $A_{600}$ reached 0.8-1.0. $\beta$-Galactosidase activity was measured as described by Guarente (1983).

\section{CAT cotransfection experiments}

The CAT cotransfection assay was done essentially as described (Nakagoshi et al. 1990). A mixture of DNAs described in the legends to Figures 5-7 was transfected into African green monkey kidney cells (CV-1) or mouse fibroblast NIH-3T3 cells. The total amount of DNA was adjusted by adding the control effector plasmid DNA. The amounts of lysates used for the CAT assay were normalized with $\beta$-galactosidase activity expressed from the internal control plasmid pact- $\beta$-gal. All CAT cotransfection experiments were repeated at least three times. Typical results and the average of three independent experiments with standard deviations are shown in Figures 5-7.

\section{Western blot analysis of c-Myb proteins}

A mixture of the plasmid DNAs described in the legends to Figres 5 and 6 was transfected into CV-1 or NIH-3T3 cells as described above for CAT cotransfection experiments. Fortyeight hours after transfection, the cell lysates were prepared and $\beta$-galactosidase activity was measured using a sample of cell lysates as was performed for CAT assays. Appropriate amounts of extracts /the precise amounts were normalized with respect to $\beta$-galactosidase activity) from each transfection sample were separated by $10 \%$ SDS-PAGE followed by blotting to nitrocellulose membranes. Blots were blocked in phosphate-buffered saline (PBS: $130 \mathrm{~mm} \mathrm{NaCl}, 2.7 \mathrm{~mm} \mathrm{KCl}, 10 \mathrm{~mm}$ potassium phosphate buffer at $\mathrm{pH} 7.2)$ containing $1.5 \% \mathrm{BSA}$ and $1.5 \%$ skim milk. c-Myb was detected by using the anti-c-Myb monoclonal antibody 1-1 (Ramsay et al. 1989), alkaline phosphatase-conjugated anti-mouse IgG, and a color development reagent (Promega).

\section{Acknowledgments}

We thank R.H. Goodman for the gift of mouse CBP cDNA and pBTM-CBD DNA, R. Eckner for the gift of the ElA mutant expression plasmid, M.R. Montminy for the gift of CREB cDNA, C. Kedinger for the gift of ElA cDNA, and N. Arai for the gift of the SR $\alpha$ promoter construct.

The publication costs of this article were defrayed in part by payment of page charges. This article must therefore be hereby marked "advertisement" in accordance with 18 USC section 1734 solely to indicate this fact.

\section{References}

Arany, Z., W.B. Sellers, D.M. Livingston, and R. Eckner. 1994. E1A-associated p300 and CREB-associated CBP belong to a conserved family of coactivators. Cell 77: 799-800.

Arany, Z., D. Newsome, E. Oldread, D.M. Livingston, and R. Eckner. 1995. A family of transcriptional adapter proteins targeted by the E1A oncoprotein. Nature 374: 81-84.

Arias, J., A.S. Alberts, P. Brindle, F.X. Claret, T. Smeal, M. Karin, J. Feramisco, and M. Montminy. 1994. Activation of cAMP and mitogen responsive genes relies on a common nuclear factor. Nature 370: 226-229.

Biedenkapp, H., U. Borgmeyer, A.E. Sippel, and K.-H. Klempnauer. 1988. Viral myb oncogene encodes a sequence-specific DNA binding activity. Nature 335: 835-837.

Bannister, A.J. and T. Kouzareides. 1995. CBP-induced stimulation of c-Fos activity is abrogated by E1A. EMBO J. 14: 47584762.

Buratowski, S. 1994. The basics of basal transcription by RNA polymerase II. Cell 77: 1-3.

Chrivia, J.C., R.P.S. Kwok, N. Lamb, M. Hagiwara, M.R. Montminy, and R.H. Goodman. 1993. Phosphorylated CREB binds specifically to the nuclear protein CBP. Nature 365: 855-859.

Clarke, M.F., J.F. Kukowska-Latallo, E. Westin, M. Smith, and E.U. Prochownik. 1988. Constitutive expression of a c-myb cDNA blocks Friend murine erythroleukemia cell differentiation. Mol. Cell. Biol. 8: 884-892.

Dini, P.W. and J.S. Lipsick. 1993. Oncogenic truncation of the first repeat of c-Myb decreases DNA binding in vitro and in vivo. Mol. Cell. Bicl. 13: 7334-7348.

Dubendorff, J.W., L.J. Whittaker, J.T. Eltman, and J.S. Lipsick. 1992. Carboxy-terminal elements of c-Myb negatively regulate transcriptional activation in cis and in trans. Genes \& Dev. 6: 2524-2535.

Duprey, S.P. and D. Boettiger. 1985. Developmental regulation of c-myb in normal myeloid progenitor cells. Proc. Natl. Acad. Sci. 82: 6937-6941.

Durfee, T., K. Becherer, P.-L. Chen, S.-H. Yeh, Y. Yang, A.E. Kilburn, W.-H. Lee, and S.J. Elledge. 1993. The retinoblastoma protein associates with the protein phosphatase type 1 catalytic subunit. Genes \& Dev. 7: 555-569.

Eckner, R., M.E. Ewen, D. Newsome, M. Gerdes, J.A. DeCapiro, J.B. Lawrence, and D.M. Livingston. 1994. Molecular cloning and functional analysis of the adenovirus E1A-associated $300-\mathrm{kD}$ protein $(\mathrm{p} 300)$ reveals a protein with properties of a transcriptional adaptor. Genes \& Dev. 8: 869-884.

Evans, J.T., T.L. Moore, W.M. Kuehl, T. Bender, and J.P.-Y. Ting. 1990. Functional analysis of c-Myb protein in T-lymphocytic cell lines shows that it trans-activates the c-myc promoter. Mol. Cell. Biol. 10: 5747-5752.

Fields, S. and O. Song. 1989. A novel genetic system to detect protein-protein interactions. Nature 340: 245-246.

Gewirtz, A.M. and B. Calabretta. 1988. A c-myb antisense oligodeoxynucleotide inhibits normal human hematopoiesis in vitro. Science 242: 1303-1306.

Golay, J., L. Loffarelli, M. Luppi, M. Castellano, and M. Introna. 1994. The human A-myb protein is a strong activator of transcription. Oncogene 9: 2469-2479.

Gonda, T.J. and D. Metcalf. 1984. Expression of $m y b, m y c$, and fos proto-oncogenes during the differentiation of a murine myeloid leukaemia. Nature 310: 249-251.

Gonzalez, G.A. and M.R. Montminy. 1989. Cyclic AMP stimulates somatostatin gene transcription by phosphorylation of CREB at serine 133. Cell 59: 675-680.

Goodrich, J.A. and R. Tjian. 1994. TBA-TAF complexes: Selec- 
tivity factors for eukaryotic transcription. Curr. Opin. Cell Biol. 6: 403-409.

Graf, T. 1992. Myb: A transcriptional activator linking proliferation and differentiation in hematopoietic cells. Curr. Opin. Genet. Dev. 2: 249-255.

Guarente, L. 1983. Yeast promoters and lacZ fusions designed to study expression of cloned genes in yeast. Methods Enzymol. 101: 181-191.

Higuchi, R. 1990. Using PCR to engineer DNA. In PCR technology: Principles and application for DNA amplification (ed. H.A. Erlich), pp.61-70. Stockton Press, New York, NY.

Hu, Y., R.G. Ramsay, C. Kanei-Ishii, S. Ishii, and T.J. Gonda. 1991. Transformation by carboxyl-deleted Myb reflects increased transactivating capacity and disruption of a negative regulatory domain. Oncogene 6: 1549-1553.

Kalkbrenner, F., S. Guehmann, and K. Moeling. 1990. Transcriptional activation by human c-myb and $\mathrm{v}-m y b$ genes. Oncogene 5: 657-661.

Kanei-Ishii, C., E.M. MacMillan, T. Nomura, A. Sarai, R.G. Ramsay, S. Aimoto, S. Ishii, and T.J. Gonda. 1992. Transactivation and transformation by Myb are negatively regulated by a leucine-zipper structure. Proc. Nat1. Acad. Sci. 89: 3088-3092.

Kwok, R.P.S., J.R. Lundblad, J.C. Chrivia, J.P. Richards, H.P. Bachinger, R.G. Brennan, S.G.R. Roberts, M.R. Green, and R.H. Goodman. 1994. Nuclear protein CBP is a coactivator for the transcription factor CREB. Nature 370: 223-226.

Lee, J.-S., K.M. Galvin, R.H. See, R. Eckner, D. Livingston, E. Moran, and Y. Shi. 1995. Relief of YYl transcriptional repression by adenovirus ElA is mediated by ElA-associated protein p300. Genes \& Dev. 9: 1188-1198.

Leff, T., R. Elkaim, C.R. Goding, P. Jalinot, C.P. Sassone, M. Perricaudet, C. Kedinger, and P. Chambon. 1984. Individual products of the adenovirus $12 S$ and 13 S Ela mRNAs stimulate viral EIIa and EIII expression at the transcriptional level. Proc. Natl. Acad. Sci. 81: 4381-4385.

Lundblad, J.R., R.P.S. Kwok, M.E. Laurance, M.L. Harter, and R.H. Goodman. 1995. Adenoviral E1A-associated protein p300 as a functional homologue of the transcriptional coactivator CBP. Nature 374: 85-88.

Maekawa, T., S. Matsuda, J. Fujisawa, M. Yoshida, and S. Ishii. 1991a. Cyclic AMP response element-binding protein, CREBP1, mediates the ElA-induced but not the Tax-induced trans-activation. Oncogene 6: 627-632.

Maekawa, T., T. Sudo, M. Kurimoto, and S. Ishii. 1991b. USFrelated transcription factor, HIV-TFl, stimulates transcription of human immunodeficiency virus-1. Nucleic Acids Res. 19: 4689-4694.

Mücenski, M.L., K. McLain, A.B. Kier, S.H. Swerdlow, C.M. Schereiner, T. A. Miller, D.W. Pietryga, W.J. Scott, and S.S. Potter. 1991. A functional c-myb gene is required for normal murine fetal hepatic hematopoiesis. Cell 65: 677-689.

Nakagoshi, H., T. Nagase, C. Kanei-Ishii, Y. Ueno, and S. Ishii. 1990. Binding of the $c-m y b$ proto-oncogene product to the simian virus 40 enhancer stimulates transcription. $I$. Biol. Chem. 265: 3479-3483.

Nakagoshi, H., C. Kanei-Ishii, T. Sawazaki, G. Mizuguchi, and S. Ishii. 1992. Transcriptional activation of the c-myc gene by the $\mathrm{c}-m y b$ and B-myb gene products. Oncogene 7: 12331240.

Ness, S.A., A. Marknell, and T. Graf. 1989. The v-myb oncogene product binds to and activates the promyelocyte-specific mim-1 gene. Cell 59: 1115-1125.

Nishina, Y., H. Nakagoshi, F. Imamoto, T.J. Gonda, and S. Ishii. 1989. Trans-activation by the c-myb proto-oncogene. $\mathrm{Nu}$ cleic Acids Res. 17: 107-117.
Nomura, N., M. Takahashi, M. Matsui, S. Ishii, T. Date, S. Sasamoto, and R. Ishizaki. 1988. Isolation of human cDNA clones of $m y b$-related genes, A-myb and B-myb. Nucleic Acids Res. 16: 11075-11089.

Nomura, T., N. Sakai, A. Sarai, T. Sudo, C. Kanei-Ishii, R. G. Ramsay, D. Favier, T. J. Gonda, and S. Ishii. 1993. Negative autoregulation of $\mathrm{c}-\mathrm{Myb}$ activity by homodimer formation through the leucine zipper. /. Biol. Chem. 268: 21914 21923.

Ogata, K., H. Hojo, S. Aimoto, T. Nakai, H. Nakamura, A. Sarai, S. Ishii, and Y. Nishimura. 1992. Solution structure of a DNA-binding unit of Myb: A helix-turn-helix-related motif with conserved tryptophans forming a hydrophobic core. Proc. Natl. Acad. Sci. 89: 6428-6432.

Ogata, K., S. Morikawa, H. Nakamura, A. Sekikawa, T. Inoue, H. Kanai, A. Sarai, S. Ishii, and Y. Nishimura. 1994. Solution structure of a specific DNA complex of the Myb DNA-binding domain with cooperative recognition helices. Cell 79: 639-648.

Ogata, K., S. Morikawa, H. Nakamura, H. Hojo, S. Yoshimura, R. Zhang, S. Aimoto, Y. Ametani, Z. Hirata, A. Sarai, S. Ishii, and Y. Nishimura. 1995. Comparison of the free and DNA complexed forms of the DNA-binding domain from c-Myb. Nature Struct. Biol. 2: 309-320.

Petrij, F., R.H. Giles, H.G. Dauwerse, J.J. Saris, R.C.M. Hennekam, M. Masuno, N. Tommerup, G.B. van Ommen, R.H. Goodman, D.J.M. Peters, and M.H. Breuning. 1995. Rubinstein-Taybi syndrome caused by mutations in the transcriptional co-activator CBP. Nature 376: 348-351.

Ramsay, R.G., S. Ishii, Y. Nishina, G. Soe, and T.J. Gonda. 1989. Characterization of alternate and truncated forms of murine c-myb proteins. Oncogene Res. 4: 259-269.

Sakura, H., C. Kanei-Ishii, T. Nagase, H. Nakagoshi, T.J. Gonda, and S. Ishii. 1989. Delineation of three functional domains of the transcriptional activator encoded by the c-myb protooncogene. Proc. Natl. Acad. Sci. 86: 5758-5762.

Shi, Y., E. Seto, L.S. Chang, and T. Shenk. 1991. Transcriptional repression by YYl, a human GLI-Kruppel related protein, and relief of repression by adenovirus E1A protein. Cell 67: 377-388.

Smith, D.B. and K.S. Johnson. 1988. Single-step purification of polypeptides expressed in Eschericha coli as fusions with glutathione S-transferase. Gene 67: 31-40.

Stein, R.L., M. Corrigan, P. Yaciuk, J. Whelan, and E. Moran. 1990. Analysis of ElA-mediated growth regulation functions: Binding of the 300-kilodalton cellular product correlates with E1A enhancer repression function and DNA synthesis-inducing activity. I. Virol. 64: 4421-4427.

Takahashi, T., H. Nakagoshi, A. Sarai, N. Nomura, T. Yamamoto, and S. Ishii. 1995. Human A-myb gene encodes a transcriptional activator containing the negative regulatory domains. FEBS Lett. 358: 89-96.

Takebe, Y., M. Seiki, J. Fujisawa, P. Hoy, K. Yokota, K. Arai, M. Yoshida, and N. Arai. 1988. SR $\alpha$ promoter: an efficient and versatile mammalian cDNA expression system composed of the simian virus 40 early promoter and the R-U5 segment of human T-cell leukemia virus type 1 long terminal repeat. Mol. Cell. Biol. 8: 466-472.

Tanikawa, J., T. Yasukawa, M. Enari, K. Ogata, Y. Nishimura, S. Ishii, and A. Sarai. 1993. Recognition of specific DNA sequences by the c-myb proto-oncogene product-role of three repeat units in the DNA-binding domain. Proc. Natl. Acad. Sci. 90: 9320-9324.

Tashiro, S., Y. Takemoto, H. Handa, and S. Ishii. 1995. Cell type-specific trans-activation by the B-myb gene product: Requirement of the putative cofactor binding to the C-ter- 
Dai et al.

minal conserved domain. Oncogene 10: 1699-1707.

Tjian, R. and T. Maniatis. 1994. Transcriptional activator: A complex puzzle with few easy pieces. Cell 77: 5-8.

Todokoro, K., R.J. Watson, H. Higo, H. Amanuma, S. Kuramochi, H. Yanagisawa, and Y. Ikawa. 1988. Down-regulation of $c-m y b$ gene expression is a prerequisite for erythropoietininduced erythroid differentiation. Proc. Natl. Acad. Sci. 85: 8900-8904.

Trauth, K., B. Mutschler, N.A. Jenkins, D.J. Gilbert, N.G. Copelend, and K.-H. Klempnauer. 1994. Mouse A-myb encodes a trans-activator and is expressed in mitotically active cells of the developing central nervous system, adult testis and $B$ lymphocytes. $E M B O ~ I .13: 5994-6005$.

Vojtek, A.B., S.M. Hollenberg, and J.A. Cooper. 1993. Mammalian Ras interacts directly with the serine/threonine kinase Raf. Cell 74: 205-214.

Westin, E.H., G.C. Gallo, S.K. Arya, A. Eva, L.M. Souza, M.A. Baluda, S.A. Aaronson, and F. Wong-Staal. 1982. Differential expression of the $a m v$ gene in human hematopoietic cells. Proc. Natl. Acad. Sci. 79: 2194-2198.

Weston, K. and J. M. Bishop. 1989. Transcriptional activation by the $\mathrm{v}-m y b$ oncogene and its cellular progenitor, $\mathrm{c}-\mathrm{myb}$. Cell 58: 85-93.

Whyte, P., N.M. Williamson, and E. Harlow. 1989. Cellular targets for transformation by the adenovirus E1A proteins. Cell 56: $67-75$.

Yasukawa, T., C. Kanei-Ishii, T. Maekawa, J. Fujimoto, T. Yamamoto, and S. Ishii. 1995. Increase of solubility of foreign proteins in Escherichia coli by coproduction of the bacterial thioredoxin. I. Biol. Chem. 270: 25328-25331. 


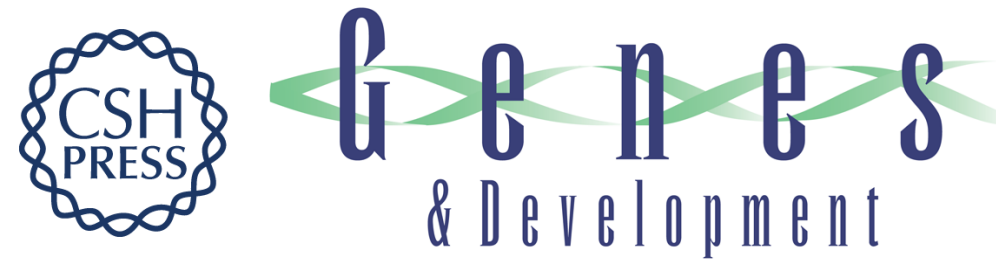

\section{CBP as a transcriptional coactivator of c-Myb.}

P Dai, H Akimaru, Y Tanaka, et al.

Genes Dev. 1996, 10:

Access the most recent version at doi:10.1101/gad.10.5.528 $\begin{array}{ll}\text { References } & \begin{array}{l}\text { This article cites } 59 \text { articles, } 21 \text { of which can be accessed free at: } \\ \text { http://genesdev.cshlp.org/content/10/5/528.full.html\#ref-list-1 }\end{array}\end{array}$

License

Email Alerting

Receive free email alerts when new articles cite this article - sign up in the box at the top Service right corner of the article or click here.

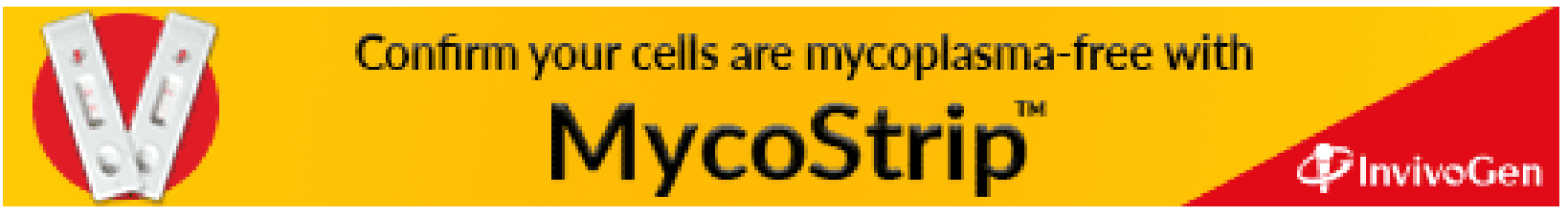

